\title{
Anti-Ly6E Antibody-Drug Conjugate RG 7841
}

National Cancer Institute

\section{Source}

National Cancer Institute. Anti-Ly6E Antibody-Drug Conjugate RG 7841. NCI Thesaurus.

Code C116745.

An antibody-drug conjug ate (ADC) composed of an antibody against the tumorassociated antigen (TAA) lymphocyte antigen 6 complex locus E (Ly6E) and linked to an as of yet undisclosed cytotoxic agent, with potential antineoplastic activity. Upon intravenous administration, the antibody moiety of RG 7841 targets and binds to Ly6E expressed on tumor cells. Upon binding and internalization, the cytotoxic agent is released and kills, through an as of yet unknown mechanism of action, the Ly6Eexpressing cancer cells. Ly6E, an interferon (IFN)-inducible glycosylphosphatidylinositol (GPI)-linked cell membrane protein, is expressed on a variety of tumor cell types. 